a kennel in the cold weather. The dog conld have inoculated his master with the secretions from lis nose and mouth.

CAsw 2.-The patient, a boy of 0 years, was brought to my oflice Aug. 9, 1912, to be treated for a bite inflicted by his pet dog. I saw him about an hour after the injury and applied a 1 per cent. solution of formaldehyd and then used tincture of iolin. The wound healed nicely. The boy then accompanied his purents on a trip to Canada, leaving here August 23. While in Canada, on the 30th, the boy had a little fever and compluined of his neck being stiff. The fumily immediately returned to Elmluust, arriving here September 1 . I saw the boy at this time; he lind a slight fever (temperature 101), and did not complain greatly. He had pain in the bnek of his neek and in his head, and he felt weak. His reflexes were present and he was able to stand and walk. When 1 saw hint the next morning he was paralyzed in all of his extremities; the chest and neck muscles were also involved. The reflexes were absent. 3r. Alt saw the patient with me and called it infuntile paralysis. Dr. J'Orsay Hecht nlso saw bim a few weeks later and agreed to the dingnosis. The boy is gradually recovering.

\section{A NEW 'TONSII,-SNARIE}

\section{W. Tikely Simpson, M.D., Mempins, Tenn.}

T'le snure shown in the necompanying illustration eonsists of a large and a small tube and a handle set at a right angle to the tubes. 'The small tube is attached to the posterior shank of the handle and is inserted within the large tule, which is attached to the anterior shank of the landle. A small wheel is attached with the small tube to the posterior shank of the handle. Both tubes are so attached to the shanks that they can move up and down. As the instrument is opened the small inner tube has a tendency to move upward and the large onter tube downward, but both working together make a tube which moves neither up nor down.

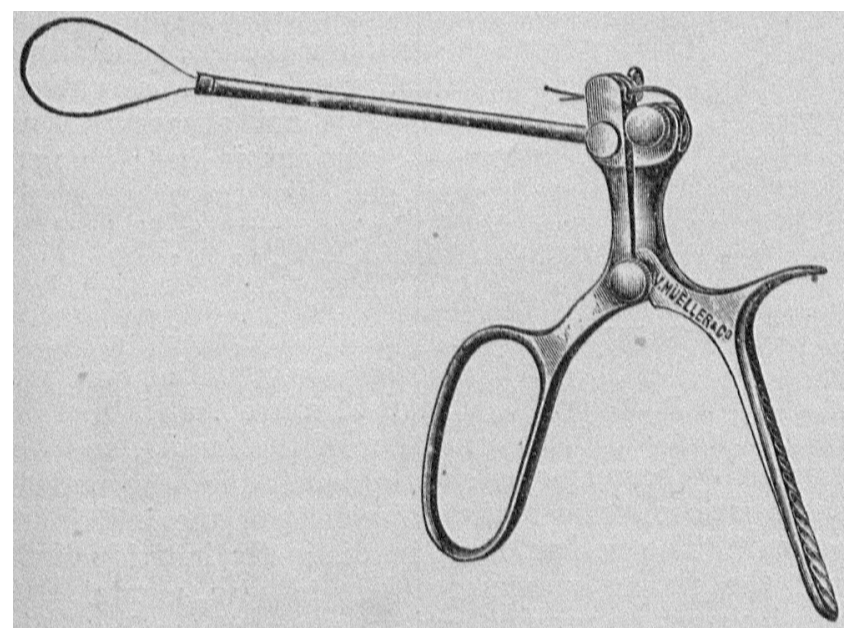

The wire sling, instead of being fixed to the small inner tube as in other snares, goes entirely through both tubes, around the small wheel at the posterior end of the small tube and forward to the attachment of the large tube with tho unterior shumk of the landle, doubling itself, where it is fustened with a serew. 'This is a most important feature of this snare, since the instrument can thus be made quite small; it will, however, close entirely over a wire loop largel thu would be necessary for any tonsil. I would suggest the freeing of the tonsil from adhesions to the pillars or adhesions in the supratonsillar fossa, but 1 do not consider it necessary to disseet the tonsil from its normal bed in any way; when it is freed from adlesions, the tonsil and its cajsule ean be pulled through the snare without harm to the pillars. If there are no adhesions, the tonsil can be entirely removed in its capsule liy pulling it well through the snare shutting down on the base.

The advantages of this snare are: It is sufficiently powerful to remove any tonsil; it hats a handle with n powerful grip set at a right angle to the tubes of the snare, which is to be pre- fered to a snare with a straight pull backward in the direction of the tubes. One can exert the whole power of the hand if necessary, which is impossible in the ordinary snare. The tubes being movalle up and down, the instrument can be opened and closed with ease.

\section{A COMPRESSED-AIR OINTMENT APPLICATOR AND JISTTRIBUTOR}

Danili. W. Layman, M.D., Indianapolis

Attending Oto-Laryngologist, Indianapolis City Hospltal anả Indianapolts Orphin Asylum

Ointments as remelial ngents to the nasal mueosa have not been extensively used, the nasal donehe or spray being the more popular form of appliration, chiefly beenuse remedial agents ean be readily and oasily applied in a fluid state.

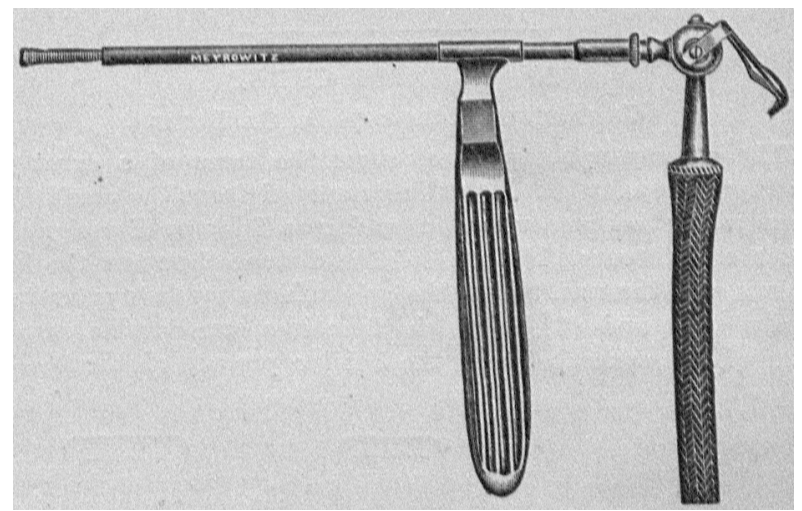

Fig. 1.-Compressed-alr ointment npplientor and distributor.

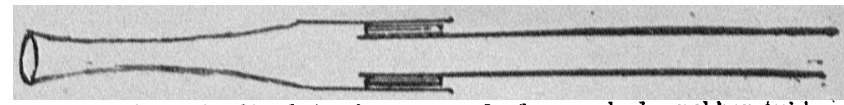

Fly. 2.-Gluss the fitted flemly over end of eannula by rubber tublug.

Ointments have been used principally to protect the skin and mucous membrune at the entrance of the nostrils from being excoriated by irritating nasal discharges. Ocensionally they are used to protect the margins of a perfornting ulcer of the septum or to stimulate grumulation tissue to a more healthy netion. It is certain that a greater quantity of active agents can be delivered to the nasal mucous membrane and can be retained for a longer period in ointment form than in the tluid state.

The objection to the use of ointments in the nose is the crude and ineflicient methods of application. When pressed from a conical tube, the ointment is not carried beyond the anterior nasal chamber. When applied with a cotton-wound applicator (the method mostly used by rhinotogists), the ointment is difficult to upply, as it adheres to the cotton closer thun to the mucous membrane. At best, the ointment can reneh only a limited area in the upper nasal chamber, and camot reach the greater part of the ethmoid region and the area included in Ballenger's "vicions eircle."

For the application of ointments to the nasal mucosa I have devised an instrument by mens of which the ointment is applied und distriluted by compressed air. This instrument (lig. 1) consists of a metal cannula with a handle, or holder, and a glass tube. The opening of the enmula at the landle end is made to reeive the tip of a compressed-air cut-off. In the latest model (Fig. 2), a glass tube is mado to fit smugly over the other end of the camula by means of $n$ piece of rubber tubing. The tube is about 2 inches in length, and is made of glass for clennliness and in order to gauge accurntely the amount of ointment to be used. The tip is flaring, something like the end of $n$ blunderbuss. With this instrument the application of ointments to the nasal mucosa is a simple procedure. The tips of many of the small collapsible ointment tubes on the market fit into the open end 
of the glass tube. When the ointment tube is thus inserted, is much of the ointment as is desired is deposited in the gluss tube by pressure with the fingers. A blast of air of 15 or 20 pounds' pressure is passed through the cannula, from which it shoots the ointment to the parts directed, applying and distributing it over a considernble area of mucous surfuce and into small recesses or openings where the cotton-wound applicator cannot reach.

Nasal medieation in ointment form is becoming more popular with rhinologists. Text-books on diseases of the nose and throut recommend ointments as valunble remedial measures. If any instruction is given as to application, it rums as follows: "Insert the elongatec tube into the nostril and jress slightly, or apply on pledget of absorbent cotton in the usual way."

The instrument 1 have described has been worked out to improve on this old method.

\section{AN ADENOID CURET}

Greenifild St,uner, M.D., S't. Louis

The accompanying pictures show the form of a curet the cutting edge of which is further removed from the shaft than in uny curet at present made, so far as I know. I designed it for use in throuts (1) in which the distance between the hard palate and the rostrum of the sphenoid is much greater than the average and (2) in which there is a considerable excavafion of the space between the basilar process of the occiput

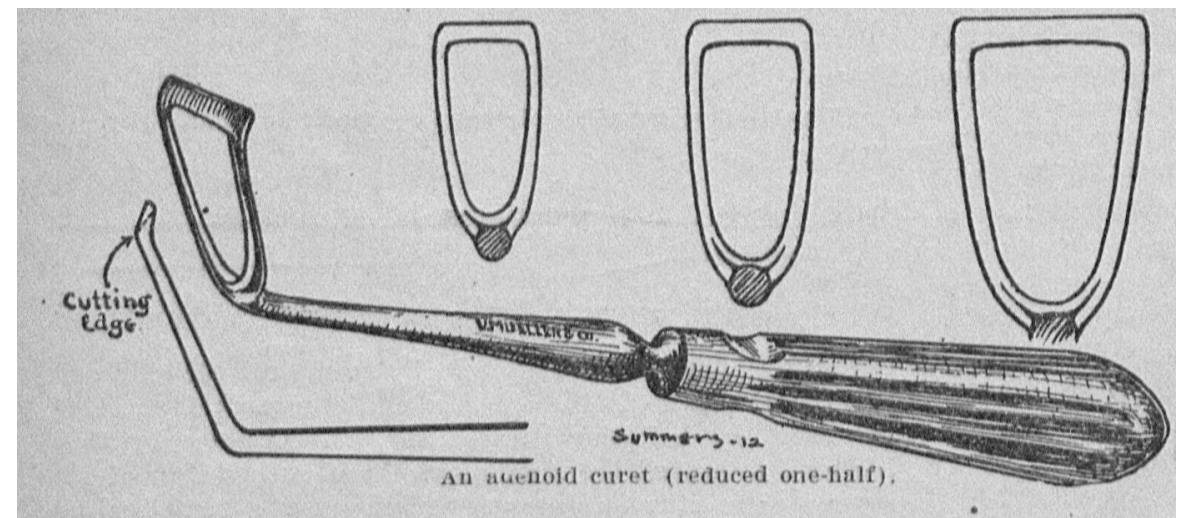

\section{DISTURBANCES OF THE HEART}

(Continued from paue 2s:5)

\section{TREATMLNT OF BROKEN COMPENSA'TON}

The consideration of this subject will include the following topies:

A. Hygiene.

B. Diet.

C. Jilimination.

D. Physical measures.

E. Medieation.

1. Cardiac Tonies: Digitalis, strophanthus, caffein, strychinin.

2. Carline Stimulants: Camphor, alcohol, ammonia.

3. Vasodilators: Nitrites, jodids, thyroid extract.

4. Cardiac Nutritives: Iron, calcium.

5. Cardine Emergency Drugs: Hrot, suprarenal active principle, pituitary active principle, atropin, norphin, and also some of the drugs already mentioned.

\section{A. MYGIMNE}

Of all treatment for broken compensation or dilated heart nothing equals rest in bed. Sometimes it is the only treatment that is needed. 'The rigidness of this rest, the length of time that it should endure, and the period at which relaxation of such rest should be allowed depend entirely on the individual patient; no iule can be established. Most of the symptoms must disappear before exercise is allowed. Perhaps a not infrequent exception to the rule is when cardiac weakness, generally a myocarditis, develops in a patient after 50. It is not always wise to keep such a patient in bed; he may bo rested and lis exereise grently restricted, but sometimes it is difficult to get him out of bed if he is lept there any length of time.

and the atlas. When this space exists it may harbor a eonsiderable amount of lymphoid tissuc which cannot be removed l,y any of the curets of the usual form. The upright portion of this one is tilted lackward to an angle of 120 dègrees, which permits it to reach upward and backward into this space. In using it for this purpose I begin by holding the shaft against the upper ineisors and hard palate.

1 have found that this instrument frequently serves well in removing tissue from the fossa of Rosemmuller. I have three sizes.

3542 Washington Avenue.

The Triumph of Hygiene.-For centuries man has tried to turn back, or at least to control disease by cure, yet knowing since the days of the creation of the mythologic Hygeia that prevention was the rational course. At no period in history has this truth been more forcibly shown than in the last quarter century by the triumph of hygiene over yellow fever. In connection with that disease therapenties bore no burden. Not a single medicine in all materia medica had the least effect. Prevention, and it alone, has abolished yellow fever. And this hoad application of hygiene to the masses brings wholesale Jealth. And it should be noted that, as with typhoid fever, the prevention of one case prevents three cases of other diseases. Jusiness has profited greatly by this triumph of hygiene over yellow fever, and government and morals and all other celements of civilization also.-J. N. Hurty in Am. Jour. Public Health.
Fresh air, sunlight and anything clse that makes the bedroom attractive and cheerful are essential and will aid in the recovery. The kind of nurse that is nected, trained, untrained, or a member of the fumily, and the amount of company or entertainment that the patient shall have must be entirely decided for the individual patient. The patient must be distinctly individualized and the proper measures taken to give mental and physical rest, to prevent excitement, worry, melancholia and depression, and to improve the general nutrition of the body as well as the condition of the heart.

Each occurrence of broken compensation in valvular disease causes another attack of cardiac weakness to oceur with less excuse than before, and several serious attacks of broken compensation mean before long the loss of the heart muscle's ability to recover, so that permanent dilatation occurs.

\section{B. DIET}

The food given should be just sufficient for the needs of the body; the patient should not be overfed or underfed. Any large bulk of food or liquid should not be given. Presstale on the heart causes discomfort and is therefore inadvisable. Food that causes flatulence should be avoided. Theoretically the patient should receive a little meat, an egg or two, cereal or bread, a small amount of simple vegetables, a little fruit, often milk, 